\title{
Training and mobility
}

Citation for published version (APA):

de Grip, A., Heijke, J. A. M., \& Willems, E. J. T. A. (1991). Training and mobility. Researchcentrum voor Onderwijs en Arbeidsmarkt, Faculteit der Economische Wetenschappen. ROA Research Memoranda No. 5E https://doi.org/10.26481/umaror.199105E

Document status and date:

Published: 01/01/1991

DOI:

10.26481/umaror.199105E

Document Version:

Publisher's PDF, also known as Version of record

\section{Please check the document version of this publication:}

- A submitted manuscript is the version of the article upon submission and before peer-review. There can be important differences between the submitted version and the official published version of record.

People interested in the research are advised to contact the author for the final version of the publication, or visit the DOI to the publisher's website.

- The final author version and the galley proof are versions of the publication after peer review.

- The final published version features the final layout of the paper including the volume, issue and page numbers.

Link to publication

\footnotetext{
General rights rights.

- You may freely distribute the URL identifying the publication in the public portal. please follow below link for the End User Agreement:

www.umlib.nl/taverne-license

Take down policy

If you believe that this document breaches copyright please contact us at:

repository@maastrichtuniversity.nl

providing details and we will investigate your claim.
}

Copyright and moral rights for the publications made accessible in the public portal are retained by the authors and/or other copyright owners and it is a condition of accessing publications that users recognise and abide by the legal requirements associated with these

- Users may download and print one copy of any publication from the public portal for the purpose of private study or research.

- You may not further distribute the material or use it for any profit-making activity or commercial gain

If the publication is distributed under the terms of Article $25 \mathrm{fa}$ of the Dutch Copyright Act, indicated by the "Taverne" license above, 


\section{TRAINING AND MOBILITY}

ROA-RM-1991/5E

A. De Grip, J.A.M. Heijke, E.J.T.A. Willems

RESEARCH CENTRE FOR EDUCATION AND LABOUR MARKET

Faculty of Economic Sciences

Rijksuniversiteit Limburg

Maastricht, July 1991 


\section{CONTENTS}

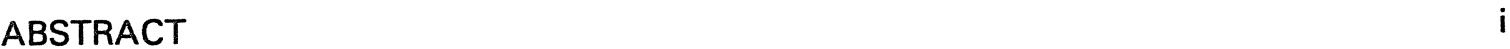

ACKNOWLEDGEMENT $\quad$ ii

1. INTRODUCTION

2. HYPOTHESES WITH REGARD TO TRAINING AND MOBILITY 3

3. A SIMULTANEOUS MODEL FOR TRAINING AND MOBILITY 9

4. THE DATA AND THE VARIABLES OF THE MODEL 12

5. ESTIMATION RESULTS

6. CONCLUSIONS 


\section{ABSTRACT}

The labour market can be seen as a matching process between on the one hand the supply of occupational qualifications and on the other hand the demand for job qualifications. In fact there are two possible ways to diminish labour market imbalances between the qualifications demanded and the qualifications supplied: training and mobility. In this paper we develop an empirical model incorporating several hypotheses on training and mobility behaviour based on human capital, job matching and labour market segmentation theories. Finally we report the estimation results produced by this model based on Dutch labour market data. 


\section{ACKNOWLEDGEMENT}

This paper summarizes the main results of a study commissioned by the Dutch Organization of Labour Market Research (OSA). An extensive report of this study has been published by OSA. 


\section{INTRODUCTION}

The labour market can be seen as a matching process between on the one hand the supply of occupational qualifications and on the other hand the demand for job qualifications. Occupational qualifications can be defined as the knowledge and skills that an individual has acquired in his or her initial education or later on by attending additional courses or on-the-job training. A job is defined here as an aggregation of tasks, carried out by an individual worker in a labour organization.

The qualifications demanded are dependent, among other things, on changes in the sectoral structure of the economy and on technological and organizational developments within sectors. The qualifications supplied will be influenced by, for instance, demographic developments, such as the ageing of the labour force, and the increasing participation of women in the labour market. Of course, individual training choices also play an important role in the skill structure of the labour supply. In fact there are two possible ways to diminish labour market imbalances between the qualifications demanded and the qualifications supplied: training and mobility. In this study we define training as: the formal education and courses attended after leaving initial day time education. This definition excludes on-the-job training which is difficult to quantify.

This study focuses on these training processes in relation to job-to-job mobility. The positive correlation of training and mobility is tested within a log linear multivariate choice model of training and mobility. Moreover, several other hypotheses with regard to possible determinants of training and/or mobility processes will be tested. Apart from potential forces behind training or mobility such as technological developments and shrinking employment, several hypotheses drawn from the human capital, job matching and labour market segmentation theories are included in our analysis. The main goal of this paper is to identify the causes of training and mobility processes. Although we will make use of various labour market theories in the process, we do not intend to test the validity of these theories. After analyzing total job-to-job mobility we will also split total mobility up into internal and external mobility. Furthermore, we will analyze the possible causes of upward mobility (i.e., mobility to a higher job level).

The human capital theory states that the time given to training will decrease when someone is growing older, because the 'pay-off period' of the investment in acquiring skills is shorter for older persons. For the same reason women, who often withdraw from the labour market relatively early, and part-time workers will probably attend less training. The mobility of workers depends on their investment in human capital, and on the character of their investments: general or firm-specific. The character of the investments determines the investments' yield in 
the workers' current jobs and in other jobs.

The job matching theory explains training and mobility processes by the existence of imperfect matches between jobs and workers. Younger workers are the most mobile (the job-shopping hypothesis). The labour market segmentation theory distinguishes between a primary and a secondary segment of the labour market. Moreover, the primary segment can be divided into internal labour markets (i.e., within the firm) and craft markets (i.e., occupational markets). The internal labour market is characterized by a high level of internal mobility and many internal training facilities, whereas the craft market is characterized by mobility within the same work domain and the secondary labour market by a high level of external mobility and therefore by short job-tenure.

We start our analysis with a basic simultaneous model of training and mobility. This basic model is extended by successively making three more simultaneous training and mobility models which deal with internal, external, and upward mobility respectively.

The structure of this paper is as follows. In section 2 we discuss the various hypotheses tested in our model. Section 3 deals with the specification of the model. In section 4 we briefly describe the data set used and translate the hypotheses of section 2 into the exogenous variables used in the model. Section 5 reports on the estimation results of the analyses. Finally, section 6 states the main conclusions of this study. 


\section{HYPOTHESES WITH REGARD TO TRAINING AND MOBILITY}

In the introduction to this paper, we mentioned three labour market theories: the human capital theory, the job matching theory, and the labour market segmentation theory. Each theory tries to explain training and mobility processes from a different point of view. In this section, we will formulate several hypotheses, based on one or more of these theories. Moreover, some additional hypotheses on the effects of shrinking employment and technological developments are formulated.

\section{Human capital and job matching theories}

Two labour market theories can be distinguished within the neoclassical framework for analysis of training and mobility processes on the labour market: the human capital theory and the job matching theory. The former focuses primarily on training processes, whereas the latter focuses mainly on labour market mobility processes.

In human capital theory, training is analyzed as an optimizing individual investment decision, analogous to investments in physical capital. The costs of an additional period of training, which consist of direct costs such as tuition fees, books, etc., and indirect costs such as the earnings forgone during training, are compared with the difference between the total future income with and without the training (see, e.g., Becker, 1962 and Schultz, 1971).

The job matching theory focuses primarily on labour market mobility. The theory deals with the quality of the match between worker characteristics and job characteristics (see Jovanovic, 1979b). Workers' comparative advantages are crucial for the allocation of individual workers with different personal characteristics among jobs with different characteristics. One individual is at his or her most productive in one job, others are at their best in another job (see, e.g., Bartel and Lichtenberg, 1987). Therefore both worker characteristics and job characteristics determine labour productivity and wages, while bad matches are seen as an incentive for labour mobility in search of a better match.

Moreover, job matching theory distinguishes between jobs as search goods and jobs as experience goods. A job can be seen as a pure search good if the quality of the job-worker match can be easily verified from an inspection of the relevant job characteristics. In that case a knowledge of the job contents and the career prospects is sufficient to determine the quality of the job-worker match, whether or not the job has actually been accepted and commenced. However, if a job is seen as a pure experience good, information on the quality of the job- 
worker match can only be obtained from the actual performance of the job. Finding the best job is then a learning process with ups and downs.

From human capital theory and job matching theory several hypotheses can be derived with regard to training and mobility:

Hypothesis l: Women attend relatively less training than men.

Since women withdraw from the labour market at a relatively young age in connection with the birth and care for their children, the readiness of many women to attend training will probably be smaller, because the 'pay-off periods' of training investments will then be shorter for female workers, which will lower the returns on their investment in training. This argument holds regardless of who finances the investment (the employer or the workers themselves). However, if the employer has to finance the training, the effect of gender on attendance at training may be greater as a result of statistical discrimination (see, e.g., Arrow, 1973 and Thurow, 1975). Statistical discrimination occurs if employers think that female workers are more likely than male workers to quit. Employers will then not be inclined to invest in the training of women, whether or not the individual female worker concerned has plans to withdraw from the labour market in the near future.

Hypothesis II: Part-time workers attend relatively less training than full-time workers.

For part-time workers the pay-off period, measured in working hours, in which investments in training can be productively applied is relatively short. The willingness to attend training will therefore probably be smaller for workers who work less than the full-time working week.

Hypothesis III: Older workers attend relatively less training and are also less mobile than youngsters.

The pay-off hypothesis of the human capital theory also explains the first part of this third hypothesis: older workers have less time to recover the costs of training investments. The second part of hypothesis III, however, is related to both human capital and job matching theory. Within the human capital theory a distinction can be made between general skills with a broad versatility and firm-specific skills that only increase a worker's productivity within the firm in which the worker concerned is working. Becker (1962) was one of the first who made this distinction. Sometimes job-specific skills are also distinguished. These skills can be used in several firms, but only in the same type of job. Older workers, who generally have acquired 
more firm or job-specific human capital than young people, are therefore expected to be less mobile. Job matching theory explains the other side of the coin. Youngsters are more mobile in so far as jobs are experience goods. A good job-worker match then usually results from a learning process by means of so-called job shopping. Therefore, it is expected that younger workers, who do not yet have enough information about their job-worker match, will be relatively more mobile than older workers. So the second part of this hypothesis might be called the job shopping hypothesis.

Hypothesis IV: Job tenure has a negative effect on external mobility and a positive effect on the internal mobility of workers.

The distinction made above between general skills on the one hand and firm or job-specific skills on the other hand also enables us to distinguish between internal and external mobility processes. Job-specific skills are often acquired by 'learning by doing' or 'on-the-job training'. As these skills increase workers' productivity only within the firm where they are working, the accumulation of these skills probably leads to long job tenures and therefor to low external mobility for the workers involved (see Jovanovic, 1979a). In fact there is a mutual relation between firm-specific skills and job tenure. On the one hand, separation from the firm will be less attractive as more specific human capital is accumulated. On the other hand longer job tenures will probably lead to more firm-specific training, because firms will be more prepared to offer training facilities', if the chance of the worker quitting is small. This relation is also known as the negative duration dependency of external mobility. On the contrary, if workers acquire more job-specific or firm-specific skills, their chances of getting a better qualified job within the same firm increase. This probably results in greater internal mobility.

Hypothesis V: Over-education leads to upward mobility and under-education leads to additional training.

Recently, Sicherman and Galor (1990) have developed a theoretical model that amends the human capital theory with regard to the returns on educational investment. In their model, investments in human capital raise future earnings in two ways: directly, via the returns which can be earned in current (or first entry) jobs, and indirectly, through occupational upgrading. A worker whose educational level is above his or her job level will be more likely to obtain a better job. This upward mobility can be internal or external. Moreover, it may be expected that workers whose qualifications from initial education are below the level required for the positions

1. Formal training as well as training on-the-job. 
$-6-$

they actually hold will try to improve their job performance, and thus their job-worker match, by attending additional training.

\section{Labour market segmentation theory}

Institutional labour market theory also enables us to formulate some hypotheses on training and mobility processes in the labour market. Most prominent within this theoretical framework are the various, often rather descriptive, dual or segmentation theories (see e.g. Doeringer and Piore, 1971).

According to these labour market segmentation theories, the labour market can be seen as a dual market with two distinct segments. The so-called primary segment is characterized by stable terms of employment, favourable working conditions, high wages and fringe benefits, and, most important, good career prospects with corresponding training facilities. Jobs in the secondary segment, however, are characterized by temporary contracts, low wages, poor working conditions and hardly any career prospects or training facilities. Labour market segmentation theory suggests the following hypotheses:

Hypothesis VI: Workers in the secondary segment of the labour market have a higher external mobility and attend relatively less training.

The dead-end jobs offered in the secondary segment of the labour market require hardly any skills. The low wages and the other poor job characteristics mentioned above make these jobs very unattractive. Therefore there is little incentive for workers to stick with their jobs, which leads to high external mobility. As the secondary segment offers no career possibilities and secondary workers are unable to enter the primary segment, firms do not invest in the human capital of these workers and the workers themselves also have no incentives to attend training.

Hypothesis VII: Internal training facilities have a positive effect on internal mobility and a negative effect on external mobility.

Hypothesis VII is closely related to hypothesis IV. Doeringer and Piore (1971) divide the primary segment of the labour market into internal labour markets (within the firm) and craft markets. Within internal labour markets, active training and career policies are adopted. Workers are selected for the non-entry jobs higher in the hierarchy through internal recruiting, training facilities and career guidance. There will therefore be relatively more training and internal mobility within these internal labour markets. Because of the firm-specific character of internal 
training, the external mobility of the workers in this labour market segment will be low, whereas the internal and upward mobility will be high.

Apart from the above seven hypotheses derived from labour market theories, the model also includes three hypotheses that relate less closely to these theories.

Hypothesis VIII: Individual training and mobility decisions have a mutually positive influence on each other.

The eighth hypothesis describes the mutual dependency of workers' training and mobility behaviour within a certain period. According to human capital theory, the character of the training (general or firm-specific) will help determine the effect of the training on the various forms of mobility.

Job mobility often means that new skills have to be learned. When starting in a new job, workers usually have to attend introductory courses. It is also possible that workers attend training in order to get a better qualified job, inside or outside the firm where they are working (upward mobility). From this we would expect training and mobility to be positively correlated. There is, however, a contrasting situation: if workers acquire firm-specific skills by attending additional training, their incentives for external mobility will probably become smaller. External mobility will then be costly, because the human capital acquired is worthless on the external labour market.

Hypothesis IX: Shrinking employment in an occupational group stimulates training and increases mobility.

The argument of this hypothesis is that workers in occupational groups in which employment is shrinking have poor career prospects and the possibility of being dismissed within a short period. Therefore they will probably be prepared to search for another job. Moreover, they will probably have an incentive to attend additional training.

Hypothesis X: Technological developments demand additional training of the workers involved.

Spenner (1988) gives an overall view of the literature on the relation between technological developments and skill requirements. In the debate on this point three positions can be distinguished: the upgrading view, the downgrading view and the view that changes are mixed 
and offset one another. As additional training is required if jobs are upgraded by technological development, but also if new technology only changes the character of the skills required, without affecting the skill level, we assume here that technological development influences training in a positive way.

This means that workers in firms or sectors of industry characterized by fast technological development will have to attend additional training relatively often, due to a general upgrading of the job contents or merely because workers in these firms have to acquire the new skills required by these new technologies (for example knowledge of certain software programmes). 
$-9-$

\section{A SIMULTANEOUS MODEL FOR TRAINING AND MOBILITY}

In this paper it is supposed that both participating in training and job mobility are individual choices. Apart from personal preferences, workers' decisions on training and mobility are based upon several job or firm characteristics. In section 2, we proposed a possible mutual dependency of training and mobility behaviour within a given time span. This means that four possible individual choices can be distinguished:

- to attend training and change jobs;

- to attend training and not change jobs;

- not attend training and change jobs;

- not attend training and not change jobs.

This choice problem can be modeled using a log linear multivariate choice model. Consider the following four probabilities:

$P_{11 i}=P\left(y_{1 i}=1, y_{2 i}=1\right\}$

$P_{10 i}=P\left\{y_{1 i}=1, y_{2 i}=0\right\}$

$P_{01 i}=P\left\{y_{1 i}=0, y_{2 i}=1\right\}$

$P_{001}=P\left\{y_{1 i}=0, y_{2 i}=0\right\}$

where:

$y_{1 i}=1$ if individual $\mathrm{i}$ attends training;

$y_{1 i}=0$ if individual $\mathrm{i}$ does not attend training;

$y_{2 i}=1$ if individual $\mathrm{i}$ is mobile;

$y_{2 i}=0$ if individual $\mathrm{i}$ is not mobile. 
The model can be parameterized as follows ${ }^{2}$ :

$$
\begin{aligned}
& P_{11 i}^{*}=d^{-1} \exp \left[y_{1 i}^{*}+y_{2 i}^{*}+y_{12 i}^{*}\right] \\
& P_{10 i}^{*}=d^{-1} \exp \left[y_{1 i}^{*}\right] ; \\
& P_{01 i}^{*}=d^{-1} \exp \left[y_{2 i}^{*}\right] ; \\
& P_{00 i}^{*}=d^{-1} .
\end{aligned}
$$

in which $y_{12 i}^{*}$ is an indicator for the (in)dependence of the training and mobility decisions, and

$$
d=\sum_{\theta 1} \exp \left[y_{1 i}^{*}+y_{2 i}^{*}+y_{12 i}^{*}\right]+\sum_{\theta 2} \exp \left[y_{1 i}^{*}\right]+\sum_{\theta 3} \exp \left[y_{2 i}^{*}\right]+\sum_{\theta 4} 1
$$

\section{where:}

i e $\theta_{1}$ if individual $i$ attends training and is mobile;

$i \in \theta_{2}$ if individual $i$ attends training and is not mobile;

$i \in \theta_{3}$ if individual $i$ does not attend training and is mobile;

$i \notin \theta_{4}$ if individual $i$ does not attend training and is not mobile.

The training equation can then be specified as:

$y_{1 i}^{*}=\beta^{\prime} x_{i}$

the mobility equation as:

$y_{2 i}^{*}=\gamma^{\prime} z_{i}$

and the dependency of training and mobility by:

$y_{12 i}^{*}=\delta$

2. See, amongst others, Amemiya (1981). The superscript * indicates the continuous variables underlying the discrete probabilities used in the model. 
in which:

$\begin{array}{ll}x_{i} & =\text { vector of possible determinants of the training decision of individual } i ; \\ z_{i} & =\text { vector of possible determinants of the mobility decision of individual } i ; \\ \beta, \gamma & =\text { vectors of parameters to be estimated; } \\ \delta & =\text { parameter to be estimated. }\end{array}$

The parameters of this model can be estimated by means of the Maximum Likelihood method. The likelihood equation is:

$L=\pi_{\theta_{1}} P_{11 i}^{*} \pi_{\theta_{2}} P_{1 \theta i}^{*} \pi_{\theta_{3}} P_{\theta_{1 i}}^{*} \pi_{\theta_{4}} P_{00 i}^{*}$

or

$L=\pi_{\theta_{1}} d^{-1} \exp \left[\beta^{\prime} x_{i}+\gamma^{\prime} z_{i}+\delta\right] \pi_{\theta_{2}} d^{-1} \exp \left[\beta^{\prime} x_{i}\right] \pi_{\theta_{3}} d^{-1} \exp \left[\gamma^{\prime} z_{i}\right] \pi_{\theta_{8}} d^{-1}$

The corresponding log-likelihood, which has to be maximized, is:

$$
\begin{aligned}
\log L= & \sum_{\theta_{1}}\left\{\log d^{-1}+\beta^{\prime} x_{i}+\gamma^{\prime} z_{i}+\delta\right\}+\sum_{\theta_{2}}\left\{\log d^{-1}+\beta^{\prime} x_{i}\right\} \\
& +\sum_{\theta_{3}}\left\{\log d^{-1}+\gamma^{\prime} z_{i}\right\}+\sum_{\theta_{4}} \log d^{-1} \\
= & \sum-\log d+\sum_{\theta_{1}}\left\{\beta^{\prime} x_{i}+\gamma^{\prime} z_{i}+\delta\right\}+\sum_{\theta_{2}}\left\{\beta^{\prime} x_{i}\right\}+\sum_{\theta_{3}}\left\{\gamma^{\prime} z_{i}\right\}
\end{aligned}
$$

Note that the estimated values of the parameters in the logit model cannot be directly interpreted. The extent of the increase or decrease in the probability of training and/or mobility is dependent on the 'basic' situation. Of course, the signs of the parameters are interpretable and enable us to test the significance of the hypotheses formulated in section 2 . 


\section{THE DATA AND THE VARIABLES OF THE MODEL}

In the next section, we will present the estimation results of four variants of the model described in section 3 . We start with a basic model of training and mobility behaviour in general, followed by three models that focus on internal, external and upward mobility, respectively. However we first have to translate the hypotheses of section 2 into exogenous variables that can be used in the models. In doing so, we will also give an expectation of the estimated signs of the parameters of these and some other variables.

For the analyses, we make use of individual panel data from the labour supply survey of the Dutch Organization of Labour Market Research (OSA) for the period 1986-1988. In the 1988 round of this labour supply survey, 4,464 individuals were interviewed, of which 2,912 were also previously interviewed in 1986. After selecting respondents working in both 1986 and 1988, the data set consists of 733 individuals. The variables in the model are sex la dummy equal to 1 for women), working time (1 for those working 40 hours or more per week, and in proportion between 0 and 1 for those working less than 40 hours), and age. These variables correspond to hypotheses I, II, and III, respectively.

Hypothesis IV, regarding job tenure, is modelled using one variable for the period, measured in years, the worker has worked for the current employer, and another variable for the training period required for a good performance of the current job. This variable is 1 if the training required is longer than 6 weeks, 0 if it is less.

To model hypothesis $V$, on the influence of over-education and under-education on mobility and training, respectively, we use an indicator of the difference between the level of education of workers and their job levels.

Hypothesis VI, regarding the characteristics of the secondary segment of the labour market, is modelled by supposing that workers who are working in jobs at the lowest two lout of the seven) job levels are in a secondary labour market.

Hypothesis VII, on the effects of internal training facilities on labour mobility, is modelled by means of one dummy variable indicating the presence of an internal training system in the firm where the worker concerned is working, and another for the extent to which workers describe their skills as job-specific or firm-specific. 
Finally, hypotheses $I X$ and $X$ are modelled using data obtained from the CBS (Dutch Central Bureau of Statistics) Labour Force Survey and Automation Statistics, respectively. 'Shrinking employment' has been defined as the relative decline of employment in an occupational group during the period $1979-1985^{3}$. The 'technological development' has been defined as the relative growth in the average automation costs per sector of industry during the period 1985$1987^{4}$.

Table 1. The expected influence of the exogenous variables on training and mobility

\begin{tabular}{lllll}
\hline & total & external internal & upward \\
Variable & training & mobility & mobility & mobility
\end{tabular}

\section{Sex}

Working time

Age

Necessary training period

Job tenure

Over-education

Under-education

Low job level

Internal training system

Job or firm specific knowledge

Shrinking employment

Technological development

$+\quad$ Expected positive effect

- Expected negative effect

In table 1, the expected effects of these exogenous variables on training and mobility behaviour are briefly summarized. There were also some additional exogenous variables for the branch of study of the worker's initial education, a number of working conditions (dummy-variables) and the industrial sector, and one variable for 'high job level ${ }^{5}$ '.

3. If employment has grown during this period the variable is equal to zero.

4. If automation costs did not grow or even declined during this period, the variable has been set equal to zero.

5. As we wanted to model the effect of workers' level of education, we here have add 'high job level' as a complementary exogenous variable, because of the dependency between the level of education of workers and the variables 'low job level', 'over-education' and 'undereducation'. 


\section{ESTIMATION RESULTS}

The estimation results of the basic model of training and mobility are presented in table 2 . We will first discuss the results of the training equation and then continue with the mobility equation. It appears that the pay-off period hypotheses of the human capital theory (hypotheses I - III) are only partially confirmed. Training decreases as workers grow older, but women and part-time workers do not attend less training than other workers, as was expected.

The results show that those working at a low job level attend relatively fewer courses. This is in accordance with hypothesis VI which states that workers in the secondary segment of the labour market will probably attend less training. The parameter estimation for the variable 'internal training system' can be interpreted as supporting the interpretation of the 'low joblevel' variable. The 'internal training system' variable shows a significantly positive effect on the training decision of individual workers. So, in so far as the presence of an internal training system can be seen as an indicator of the primary segment of the labour market, workers in the primary segment do attend more training than other workers.

The workers whose qualifications were in fact not adequate for their current jobs did not attend significantly more training. The same holds for the job characteristics 'work with noise or bad smell', and 'work independence' la subjective evaluation by the worker of the independence allowed in the job) and for the variable 'work outside profession' (i.e., outside the profession which the worker considers his or her 'normal' profession). There also appears to be no significant effect of technological development on training investments. However, it has to be pointed out that the indicator of technological change which was used is far from perfect.

Furthermore, it can be noticed that those working in occupational groups with shrinking employment attend relatively less training, contrary to the expectations presented in section 2. This effect can probably be better modelled as a sectoral characteristic, based on another hypothesis: if business volume and profits, and thus employment, in an industry are shrinking, most firms will offer less internal training.

Finally, with regard to the training equation, it should be noted that workers with a medical or paramedical education attend less training. This is probably because the greater part of medical education is received before or directly after entering the labour market (the so-called in-service training). Courses for workers who already have their diplomas are obviously of minor importance. 
$-15-$

Table 2. Estimation results for the simultaneous training and mobility model

\begin{tabular}{|c|c|c|c|c|}
\hline \multirow[b]{2}{*}{ variable } & \multicolumn{2}{|c|}{$\begin{array}{l}\text { training } \\
\text { equation }\end{array}$} & \multicolumn{2}{|c|}{$\begin{array}{l}\text { mobility } \\
\text { equation }\end{array}$} \\
\hline & value & t-ratio & value & t-ratio \\
\hline Constant & 0.86 & 1.08 & 1.91 & 2.44 \\
\hline Age & -0.05 & -4.52 & -0.04 & -3.11 \\
\hline Sex & -0.01 & -0.03 & 0.00 & 0.01 \\
\hline Working time & 0.44 & 0.89 & -0.30 & -0.61 \\
\hline Over-education & \multicolumn{2}{|c|}{ not included } & 0.37 & 1.54 \\
\hline Under-education & 0.19 & 0.68 & \multicolumn{2}{|c|}{ not included } \\
\hline Job or firm specific knüwledge & 0.04 & 0.23 & -0.49 & -2.97 \\
\hline Necessary training period & 0.05 & 0.25 & 0.11 & 0.62 \\
\hline Job tenure & -0.02 & -1.16 & -0.03 & -2.29 \\
\hline Low job level & -0.69 & -2.87 & -0.81 & -2.91 \\
\hline High job level & -0.44 & -1.57 & 0.26 & 1.12 \\
\hline Work with noise or bad smell & -0.19 & -0.83 & -0.17 & -0.79 \\
\hline Work outside profession & 0.23 & 0.90 & -0.07 & -0.27 \\
\hline Work independence & 0.19 & 0.92 & -0.02 & -0.11 \\
\hline Shrinking employment & -0.04 & -3.48 & 0.01 & 1.33 \\
\hline Internal training system & 0.82 & 4.66 & 0.03 & 0.18 \\
\hline Technological development & -0.00 & -1.14 & \multicolumn{2}{|c|}{ not included } \\
\hline \multicolumn{5}{|c|}{ Branch of study of initial education, compared with general education } \\
\hline Technical & -0.16 & -0.70 & -0.39 & -1.69 \\
\hline Commercial/administrative & -0.26 & -0.79 & -0.10 & -0.31 \\
\hline Medical/para-medical/services & -0.58 & -1.86 & 0.10 & 0.34 \\
\hline Other & 0.78 & 2.29 & 0.00 & 0.00 \\
\hline \multicolumn{5}{|c|}{ Sector of industry, compared with agriculture/manufacturing } \\
\hline Commercial services & 0.29 & 1.21 & -0.39 & -1.65 \\
\hline Public services & 0.40 & 1.49 & -0.66 & -2.46 \\
\hline \multicolumn{5}{|c|}{$($ In) dependency parameter $=0.43(\mathrm{t}$-ratio $=2.44)$} \\
\hline $\begin{array}{l}\text { Log-likelihood }=-868.84 \\
n=733\end{array}$ & & & & \\
\hline
\end{tabular}

From the estimation results for the mobility equation given in table 2, we see that age has a significant effect on mobility as described in both human capital theory and job matching theory: older workers are less mobile than younger workers. However, as mentioned in section 2 , the arguments of the two theories are different. The empirical model does not enable us to distinguish between the theories on this point.

Human capital theory also says that mobility will decrease with longer job tenure, because workers with longer tenures have accumulated more firm-specific training which makes it costly 
for them to change jobs. This so-called negative duration dependency of job mobility seems to be confirmed by the estimation results.

Another conclusion that can be drawn from the estimation results is that those working at low job levels are relatively less mobile, which conflicts with the secondary labour market hypothesis (hypothesis VI). The estimation results also show that public sector workers and workers with more firm-specific or job-specific skills are relatively less mobile. Finally, the (in)dependency parameter is significantly greater than zero, which means that the hypothesis that workers take training and mobility decisions 'simultaneously' ${ }^{6}$ is confirmed.

As already noted, mobility cannot be seen as a homogeneous phenomenon. As some of the regressors used in the model are expected to have different effects on the various types of mobility, we estimated some variants of the model, distinguishing between internal, external, and upward mobility. Table 3 shows the results for the internal and external mobility equations, and in table 4 the estimation results for the upward mobility equation are given?

\section{Internal and external mobility}

Table 3 shows that the distinction between internal and external mobility is highly relevant for the estimation results. It turns out that neither age nor job tenure have a significant influence on internal mobility, only on external mobility. So older workers and/or workers with longer job tenures, who have probably accumulated many firm or job specific skills, are relatively less mobile outside their current firm. This is in accordance with both human capital and job matching theory, as described by hypothesis IV. Probably, jobs can be seen as experience goods. A long job tenure indicates a good job-worker match, and therefore the worker's propensity to change jobs is relatively small. Internal mobility, however, is not significantly influenced by workers' ages and job tenures. Moreover, it can be seen that the variable 'job or firm specific knowledge' has a negative effect on both internal and external mobility. This is rather remarkable, because one should expect that job-specific or firm-specific skills would have a positive effect on internal mobility. It is possible that multicolliniarity between the variables age, job tenure, and the amount of specific skills acquired distorts the estimation results of the

6. By 'simultaneous', we mean here that the decisions on training and mobility are both taken within the 2-year period 1986-1988.

7. Since the estimated training equation for these three models is not substantially different to the training equation presented in table 2 , we only present the estimation results of the mobility equations. 
latter variable. Another possible explanation of this result is that the concepts of firm-specific and job-specific knowledge were incorrectly interpreted by the survey respondents.

The branch of study of the worker's initial education has no statistically significant effect on internal mobility. However technically skilled workers are externally less mobile. This probably shows that these workers work, relatively often, in an internal labour market.

Another remarkable result is the positive effect of the over-education variable in the internal mobility equation, which is in accordance with the Sicherman and Galor (1990) hypothesis (hypothesis V). Obviously over-education is acceptable to a certain group of more educated workers, as a temporary situation. These workers accept less qualified jobs for a limited period and try to grow into better jobs in the same firm. Over-education does not lead to a greater external mobility.

Job level also has different effects on internal and external mobility. From labour market segmentation theory we should expect, as described in hypotheses VI, that external mobility would be relatively high for those working in the secondary segment of the labour market. If a low job level is taken as an indicator of the secondary labour market segment, the estimation results do not confirm this. The effect observed was not statistically significant. However, we do find, as expected, a significant negative relation between low job level and internal mobility, which means that those working in less qualified jobs have fewer possibilities of getting jobs higher in the hierarchy of the firms they currently work for.

The popular view that those working in the public sector have 'life-time jobs' seems (to some extent) to be confirmed by the data: public sector workers are relatively less mobile than workers in agriculture or manufacturing. We also observe that workers in the service sector have a relatively low external mobility. No relationship was found between the sector of industry and internal mobility.

Finally, it turns out that the availability of internal training facilities has a significant positive influence on internal mobility. Since the sign of this variable in the external mobility equation is negative (although not significant), the relevance of an internal training system as an indicator of the existence of an internal labour market seems to be validated. 
$-18-$

Table 3. Estimation results for the simultaneous training and internal mobility model, and for the simultaneous training and external mobility model

\begin{tabular}{|c|c|c|c|c|}
\hline \multirow[b]{2}{*}{ variable } & \multicolumn{2}{|c|}{$\begin{array}{l}\text { internal } \\
\text { mobility }\end{array}$} & \multicolumn{2}{|c|}{$\begin{array}{l}\text { external } \\
\text { mobility }\end{array}$} \\
\hline & value & t-ratio & value & t-ratio \\
\hline Constant & -2.75 & -2.55 & 2.75 & 3.00 \\
\hline Age & -0.00 & -0.17 & -0.05 & -3.59 \\
\hline Sex & 0.40 & 1.27 & -0.32 & -1.13 \\
\hline Working time & 0.72 & 1.02 & -0.96 & -1.71 \\
\hline Over-education & 0.62 & 2.04 & 0.01 & 0.04 \\
\hline Under-education & \multicolumn{2}{|c|}{ not included } & \multicolumn{2}{|c|}{ not included } \\
\hline Job or firm specific knowledge & -0.49 & -2.19 & -0.53 & -2.39 \\
\hline Necessary training period & 0.21 & 0.88 & -0.00 & -0.02 \\
\hline Job tenure & -0.01 & -0.44 & -0.04 & -2.28 \\
\hline Low job level & -1.00 & -2.46 & -0.43 & -1.36 \\
\hline High job level & 0.27 & 0.94 & 0.15 & 0.54 \\
\hline Work with noise or bad smell & -0.35 & -1.12 & 0.01 & 0.05 \\
\hline Work outside profession & -0.30 & -0.82 & 0.09 & 0.32 \\
\hline Work independence & -0.12 & -0.44 & 0.06 & 0.23 \\
\hline Shrinking employment & 0.00 & 0.20 & 0.01 & 1.17 \\
\hline Internal training system & 0.51 & 2.15 & -0.29 & -1.48 \\
\hline Technological development & \multicolumn{2}{|c|}{ not included } & \multicolumn{2}{|c|}{ not included } \\
\hline \multicolumn{5}{|c|}{ Branch of study of initial education, compared to general education } \\
\hline Technical & 0.08 & 0.25 & -0.55 & -2.06 \\
\hline Commercial/administrative & 0.15 & 0.37 & -0.34 & -0.86 \\
\hline Medical/para-medical/services & 0.13 & 0.31 & -0.01 & -0.03 \\
\hline Other & -0.18 & -0.42 & 0.13 & 0.34 \\
\hline \multicolumn{5}{|c|}{ Sector of industry, compared with agriculture/manufacturing } \\
\hline Commercial services & -0.04 & -0.13 & -0.51 & -1.88 \\
\hline Public services & -0.25 & -0.72 & -0.68 & -2.19 \\
\hline (In)dependency parameter & 0.79 & 3.35 & -0.04 & -0.19 \\
\hline Log-likelihood & -709.51 & & $\begin{array}{c}-781.37 \\
733\end{array}$ & \\
\hline 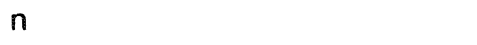 & 733 & & 133 & \\
\hline
\end{tabular}

Upward mobility

Table 4 presents the estimation results for the upward mobility equation. It can be seen that a worker's age has no significant effect on upward mobility. Older workers seem to have the same chance as younger workers of getting better qualified jobs within the firm. What is rather remarkable is the negative effect - significant at a $10 \%$ level - of the sex variable. Women, although generally not less mobile than men, apparently show relatively less upward mobility. 
Furthermore, the over-education variable has a significant positive effect, as was the case for the internal mobility equation. If someone's skill level is higher than the job level, he or she has a better chance of promotion to a better qualified job. This means that labour market entrants cannot immediately get a job commensurate with their level of education, and therefore accept less qualified jobs. Through upward mobility within the internal labour market, these workers have a good chance of getting a job at their skill level at some time. This is according to hypothesis $\mathrm{V}$.

The presence of job-specific or firm-specific knowledge has a negative effect on workers' upward mobility. Job tenure also has a negative effect, as does the variable 'high job level'. The latter effect is certainly because those working at a high job level have little or even no possibility of growing into better qualified jobs. Finally, service sector workers have a lower upward mobility.

At the end of this section, we will discuss the estimated values of the (in)dependency parameters. A significant correlation was observed between training and mobility in the basic model, and between training and mobility in the internal and upward mobility models. But in the simultaneous model of training and external mobility the (in)dependency parameter is not significantly different from zero. This means that internal and upward mobility on the one hand and attendance at training on the other hand are correlated, whereas external mobility is not related to training processes.

Several elements can play important roles in this mutual dependency. First, as has been pointed out before, training can initiate internal, external, or upward mobility, but mobility can also initiate training. So, in general there is a mutually positive relation between training and mobility behaviour. However, especially with respect to external mobility, there can also be opposite effects. If the skills acquired are firm-specific, the propensity for external mobility will probably decrease, which can explain the insignificance of the (in)dependency parameter in the training/external mobility model. The results there show the importance of the firm-specific character of workers' human capital investments. 
Table 4. Estimation results for the simultaneous training and upward mobility model

\begin{tabular}{|c|c|c|}
\hline \multirow[b]{2}{*}{ variable } & \multicolumn{2}{|c|}{$\begin{array}{l}\text { upward } \\
\text { mobility }\end{array}$} \\
\hline & value & t-ratio \\
\hline Constant & -2.08 & -1.03 \\
\hline $\begin{array}{l}\text { Age } \\
\text { Sex }\end{array}$ & $\begin{array}{l}-0.01 \\
-1.18\end{array}$ & $\begin{array}{l}-0.43 \\
-1.76\end{array}$ \\
\hline Working time & & \\
\hline Over-education & 0.22 & $\begin{array}{l}0.15 \\
2.07\end{array}$ \\
\hline Under-education & \multicolumn{2}{|c|}{ not included } \\
\hline Job or firm specific knowledge & -1.36 & -3.27 \\
\hline Necessary training period & 0.62 & 1.57 \\
\hline Job tenure & -0.08 & -2.35 \\
\hline Low job level & -0.19 & -0.34 \\
\hline High job level & -1.19 & -1.74 \\
\hline Work with noise or bad smell & -0.38 & -0.80 \\
\hline Work outside profession & -0.93 & -1.39 \\
\hline Work independence & 0.29 & 0.59 \\
\hline Shrinking employment & 0.00 & 0.01 \\
\hline Internal training system & 0.23 & 0.57 \\
\hline Technological development & \multicolumn{2}{|c|}{ not included } \\
\hline \multicolumn{3}{|c|}{ Branch of study of initial education, compared with general education } \\
\hline Technical & 0.00 & 0.01 \\
\hline Commercial/administrative & -0.89 & -1.02 \\
\hline Medical/para-medical/services & 0.49 & 0.66 \\
\hline Other & -0.71 & -0.81 \\
\hline \multicolumn{3}{|c|}{ Sector of industry, compared with agriculture/manufacturing } \\
\hline Commercial services & -0.88 & -1.79 \\
\hline Public services & -0.70 & -1.23 \\
\hline (In)dependency parameter & 1.41 & 3.32 \\
\hline $\begin{array}{l}\text { Log-likelihood } \\
\text { n }\end{array}$ & $\begin{array}{l}-540.78 \\
733\end{array}$ & \\
\hline
\end{tabular}




\section{CONCLUSIONS}

Training and mobility are two important mechanisms to diminish imbalances between qualifications demanded and supplied on the labour market. This final section summarizes the main conclusions of our empirical research into the forces behind these training and mobility processes, and their interdependency, for the Netherlands in the period 1986-1988. The estimation results show that workers' participation in training is negatively influenced by their age. This is in accordance with both the pay-off period hypothesis, derived from the human capital theory, and the job shopping hypothesis of the job matching theory. Moreover, as labour market segmentation theory says, workers with low job levels do indeed appear to participate significantly less in training activities than other workers. Workers in internal labour markets (indicated by the presence of internal training facilities), however, are significantly more involved in training processes. The estimation results also show that the training of workers is negatively influenced by shrinking employment in their occupational groups. This is probably because firms often offer less training in bad times. Finally, we find a significant correlation between training and mobility processes. The specification of the model used does not enable us to interpret the direction of the causal relation.

The estimation results of the various models also show that it is important to distinguish between internal end external mobility and to analyze upward mobility separately. The overeducation of workers has a significant positive effect on internal and upward mobility. From this we may conclude that for many workers over-education can apparently be characterized as a temporary phenomenon. In accordance with labour market segmentation theory, workers at low job levels in the secondary labour market show significantly less internal mobility, whereas workers in an internal labour market show significantly more internal mobility than other workers. However, job tenure has a significant negative influence on external mobility. This is in accordance with human capital theory, which explains this low external mobility as the result of the accumulated firm-specific human capital of workers with long job tenures.

Finally, the estimation results show that the mutual interdependency between training and mobility processes applies only to internal and upward mobility processes. External mobility and training processes are not significantly related. This can probably be explained using the distinction made in human capital theory between firm-specific and general skills, which have different effects on external mobility. 


\section{REFERENCES}

Amemiya, T. (1981), Qualitative Response Models: A Survey, Journal of Economic Literature, vol. 19, pp. 1483-1536.

Arrow, K.J. (1973), The Theory of Discrimination, in: Ashenfelter, O.; A. Rees (eds.), Discrimination in Labor Markets, Princeton, pp. 3-33.

Bartel, A.P.; F.R. Lichtenberg (1987), The Comparative Advantage of Educated Workers in Implementing New Technology, Review of Economics and Statistics, vol. 69, no. 1, pp. 111.

Becker, G.S. (1962), Investment in Human Capital: A Theoretical Analysis, Journal of Political Economy, vol. 70, no. 1, pp. 9-49

Doeringer, P.B.; M.J. Piore (1971), Internal Labor Markets and Manpower Analysis, Heath Lexington Books, Lexington.

Jovanovic, B. (1979a), Job Matching and the Theory of Turnover, Journal of Political Economy, vol. 87, no. 5, pp. 972-990.

Jovanovic, B. (1979b), Firm-specific Capital and Turnover, Journal of Political Economy, vol. 87 , no. 6, pp. $1246-1260$.

Phelps, E.S. (1972), The Statistical Theory of Racism and Sexism, American Economic Review, no. 62 , pp. 659-661.

Schultz, T.W. (1971), Investment in Human Capital: The Role of Education and of Research, Free Press, New York.

Sicherman, N.; O. Galor (1990), A Theory of Career Mobility, Journal of Political Economy, vol. 98 , no. 1 , pp. 169-192.

Spenner, K.I. (1988), Technological Change, Skill Requirements and Education: The Case for Uncertainty, in: R.M. Cyert; D.C. Mowery (eds.), The Impact of Technological Change on Employment and Economic Growth, Ballinger Publishing Company, Cambridge (Mass.), pp. 131-184.

Thurow, L. (1975), Generating inequality, MacMillan, New York. 